\title{
6 Archives and human rights beyond political transitions
}

In business circles, more needs to be done to promote the role of archives in defending human rights and in combatting impunity. As already mentioned, the UN Guiding Principles on Business and Human Rights, approved by the Human Rights Council in 2011, make no mention of the issue of access to records, although, without such access, it would be impossible to apply these principles and obtain redress (Barrientos et al., 2018). Archives are also vital in bringing the truth about human rights violations in the business world to light and offer the best sources of evidence of specific facts for use in imposing sanctions on the authors of violations and in making amends for the harm caused to victims.

These guiding principles are of crucial importance in obtaining business community endorsement of human rights. While it is not surprising that company owners and their shareholders would target profits, they may also be tempted to abuse the advantages offered by global, highly competitive markets by sacrificing their employees' social and economic rights and, in turn, weakening the foundations and wealth of a whole community and putting consumer health at risk. But, unlike the Joinet or de Greiff Principles analysed in detail earlier, the Ruggie Principles target the private sector, businesses first and foremost, which means that their application is largely dependent on the sector's willingness to play the game, because these principles do not have the same coercive force as for government institutions.

The Principles do, however, impose a variety of obligations on the States, for example that of ensuring that enterprises operating on their territory do not violate human rights or advising them on how to conduct their activities, when they operate largely abroad and in sectors wide open to violations, such as conflict zones, which places the onus squarely on government. Given the position of the victims of workplace human rights violations and the need to provide individual and collective channels for enabling them to seek redress, these Principles are also applicable to civil society organizations, such as Trade Unions, NGOs, victim associations and campaigners for human rights.

In 2017, in Geneva, the Human Rights Working Group of the International Council on Archives (HRWG) called the attention of the Forum 
responsible for monitoring application of the Ruggie Principles to the total absence of references to archives and recordkeeping in its document. Archives and records are crucial with regard to the right to know and the right to the truth in aiding governments to fulfil their supervisory role, and a key component of corporate policies and mechanisms for obtaining redress, in other words, all of the three areas covered by the Principles. The working group insisted on the importance of documents in ensuring application of these Principles to the following ends:

1 To provide States with objective information to help them fulfil the obligations incumbent upon them.

2 To provide businesses with evidence to demonstrate their commitment to human rights and deal with any eventual demands for redress they may receive under the reparations systems in place.

3 To afford civil society organizations and victims access to the documentary evidence they need to support their demands and stake their claims.

4 To help individual countries and individual businesses in drawing up action plans for implementation of these principles.

With regard to the first of these points, States must make sure that the records they produce in fulfilling their supervisory functions are preserved in the public archival system. For their part, businesses must make arrangements for their records to be properly handled to guarantee that they are held in safekeeping and can be retrieved and produced as proof of corporate transparency. NGOs and Trade Unions should also set up records departments, if only to keep track of the complaints made against businesses for abuses of human rights. Basically, archiving and archive management policies should be developed in the three areas just mentioned.

The need to document human rights violations in the business world was already mentioned earlier in a report of the UN Secretariat dated 2 July 2012 on the Contribution of the UN system as a whole to the advancement of the business and human rights agenda and the dissemination and implementation of the Guiding Principles on Business and Human Rights. The report states that "at the current time there is no global repository of information on patterns of business-related human rights impact and responses by States and business, as well as other stakeholders, to address such an impact". It is for this reason that it recommends the establishment of a comprehensive database to keep a record of "information on State initiatives and processes, corporate policies and practices, and the use of accountability mechanisms for affected stakeholders" and therefore proposes "the institutionalisation of a global repository on business and human rights within the United Nations". 49

The role of archives and records in the defence of human rights must also remain consistent in electronic environments. Computers and new technologies may offer enormous advantages in areas such as e-commerce, access to 
information and open government, but there remain issues with regard to document preservation and availability, authenticity and reliability that we cannot afford to ignore. While we may appreciate the ease with which soft copy material can be used, there is also the undeniable downside that this material is highly volatile and the information it contains extremely vulnerable. Maintaining and enhancing the capacities of archives and records for underpinning democracy and defending human rights in a digital environment is one of the biggest challenges facing us in today's new archival world. To cater to this challenge, the public authorities will need to ensure that the enormous benefits afforded by computer systems in boosting the efficiency, flexibility and transparency of their activities are, under no circumstances, allowed to undermine the democratic achievements of recent years in the preservation and accessibility of official documents and, by extension, their use by citizens as fundamental instruments for exercising their rights.

But while soft copy documents may be an undoubted boon in further underpinning democratic societies, the use of new technologies is also fraught with risk. Human rights advocates have two main concerns with regard to technological progress in respect of information and communications. The first concerns the risks inherent in the transmission systems in use and the possibility that the public or fiscal authorities may use these systems to spy on their citizens. It is not only the right to freedom of speech that is under threat through violation of our private communications but also our right to privacy and confidentiality. Their second concern is that the development of artificial intelligence could make humans superfluous to the administrative decision-making process through their replacement by self-executing routines.

Many international organizations have voiced their concerns over the issues of freedom of speech, the right to privacy and confidentiality. Their anxiety is largely triggered by the increasingly widely publicised scandals and accusations of abusive use of the possibilities for monitoring communications, and the employment of algorithms to track social media exchanges for purposes of developing individually tailored sales policies. They are also worried about the use of Internet to search for information or for business transactions. These perfectly justifiable concerns, prompted by the treatment reserved for private exchanges and the way personal data divulged by citizens is diverted for other purposes, have culminated in the adoption of data protection laws in over a hundred countries, plus international regulations with even broader scope. Among these, special mention should be made of the European Union's General Data Protection Regulation (GDPR), approved in 2016 and fully effective since 2018.

With the advent of the World Wide Web, document access has undergone a sea change, to the extent that many international human rights defence organizations see its use as a fundamental part of any democratisation process and consider that universal access to Internet and digital literacy are the only way of avoiding a truly unequal and unfair world. The Internet 
Rights and Principles Coalition, which is part of the UN Internet Governance Forum, has drafted The Charter of Human Rights and Principles for the Internet, ${ }^{50}$ in an attempt to adapt existing human rights to this new environment. The document states that "the Internet offers unprecedented opportunities for the realisation of human rights, and plays an increasingly important role in our everyday lives", adding that

It is therefore essential that all actors, both public and private, respect and protect human rights on the Internet. Steps must also be taken to ensure that the Internet operates and evolves in ways that fulfil human rights to the greatest extent possible".

Another of today's problems is that of environmental rights and their defence. Some of the best weapons when rising to the climate change challenge are open-source data, document management and transparency and the right of access to public sector information. In addition, the environmental disasters portended by climate change, with rising sea levels for example, may at times put archival buildings and records in jeopardy, especially if they are located in coastal areas. Both UNESCO and the International Council on Archives have embarked on initiatives geared towards locating such archives and evaluating the true extent of the potential risks they face. One example of these efforts is the "Survey for memory institutions, to measure the risks, damages and disasters in documentary heritage" compiled by the Secretariat of UNESCO's Memory of the World programme. ${ }^{51}$

A further complex issue is that of safe havens to be provided for archives at risk for reasons connected with wars or climate change. Following initiatives taken by UNESCO and Swisspeace, an international Working Group was established to draft Guiding principles ${ }^{52}$. These principles were issued in 2018 and later the same year approved by the ICA Executive Board. They are designed to proffer advice on the ethical and archival principles to be taken into consideration when transferring archives to other institutions for safekeeping.

One last point specifically concerns the defence of communities that are particularly vulnerable for reasons connected with their ethnic origins or economic circumstances. This is yet another massive challenge facing archives, not just as regards management of the records of the public or private sector organizations dealing with these communities (from the UN High Commissioner for Refugees to a significant number of nongovernmental organizations) but also as regards management of the many personal testimonies collected about violations of the rights of children, indigenous peoples, women or refugees. The Annual Conference of the International Council on Archives held in Adelaide (Australia) in 2019 focused on a number of major topics, one of the most important of which was the role of archives in protecting such communities..$^{53}$ This is but one of the latest developments within the ICA towards fully acknowledging 
the vital role of the archivist in relation to human rights because, as ICA President David Fricker writes in his introductory words to this book, "archives contain the evidence upon which the defence of human rights can be prosecuted".

\section{Notes}

1 In 1791, in response to the Declaration of the Rights of Man and of the Citizen, Olympe de Gouges drafted a "Declaration of the Rights of Woman and the Female Citizen", which she submitted to the National Assembly. The text was never discussed and, worse still, was not widely distributed at the time, partly because its author was sentenced to the guillotine two years later, in 1793, for having opposed the execution of Louis XVI. Olympe de Gouges was also one of the pioneers of the abolition of slavery, as evidenced by her play the Slavery of the Blacks of 1784, which was added to the repertoire of the Comédie Française in 1785 under the title Zamore et Mirza ou l'heureux naufrage. For a biography of Olympe de Gouges, see Faucheux (2018).

2 L'instauration d'un rituel civil, qu'on oppose au rituel religieux, a pour but de montrer qu'en déclarant son état-civil à l'officier municipal, un individu devient membre de la communauté des citoyens, de la même façon que le baptême supposait l'entrée dans la communauté des chrétiens [.. .] Le nouveau-né devra être "présenté" par ses parents à cette église laïque qu'est la "maison commune". C'est à partir de ces principes qu'est abordée la question proprement dite de l'identification des individus (Noiriel, 1993).

3 Transforming Our World: The 2030 Agenda for Sustainable Development, United Nations, A/RES/70/1, 2015.

4 The law was radically amended in 1974 following the adoption of the Privacy Federal Act.

5 Although, in Scandinavian countries, there exist more distant precedents with regard to the right of access to information, which date back to the 18th century, the first such law being the Swedish Freedom of the Press Act of 1766.

6 See Convention 205 of the Council of Europe on access to official documents published on 18 June 2009 and the model law on access to information of the Organization of American States adopted at the fourth plenary session held on 8 June 2010 - AG/RES. 2607 (XL-O/10).

7 Available at www.un.org/en/development/desa/population/migration/generalas sembly/docs/globalcompact/A_RES_60_1.pdf.

8 Case of Paniagua Morales et al., Verdict of 8 March 1998, para 173.

9 A/CONF.157/23.

10 C. Preservation of and access to archives bearing witness to violations: PRINCIPLE 13: Measures for the Preservation of Archives. The right to know implies that archives should be preserved. Technical measures and penalties shall be applied to prevent any removal, destruction, concealment or falsification of archives, especially for the purpose of ensuring the impunity of perpetrators of human rights violations. PRINCIPLE 14. Measures for Facilitating Access to Archives. Access to archives shall be facilitated in order to enable victims and persons related to claim their rights. Access should also be facilitated, as necessary, for persons implicated, who request it for their defence. When access is requested in the interest of historical research, authorization formalities shall normally be intended only to monitor access and may not be used for purposes of censorship. PRINCIPLE 15. Cooperation between Archive Departments and the Courts and Extrajudicial Commissions of Inquiry. The courts 
and extrajudicial commissions of inquiry, as well as the investigators reporting to them, must have free access to archives. Considerations of national security may not be invoked to prevent access. By virtue of their sovereign power of discretion, however, the courts and extrajudicial commissions of inquiry may decide, in exceptional circumstances, not to make certain information public if such publication might jeopardize the preservation or restoration of the rule of law. PRINCIPLE 16. Specific Measures Relating to Archives Containing Names. (a) For the purposes of this principle, archives containing names shall be understood to be those archives containing information that make it possible, in any way whatsoever, directly or indirectly, to identify the individuals to whom they relate, regardless of whether such archives are on paper or in computer files. (b) All persons shall be entitled to know whether their name appears in the archives and, if it does, by virtue of their right of access, to challenge the validity of the information concerning them by exercising a right of reply. The document containing their own version shall be attached to the document challenged. (c) Except where it relates to top officials and established staff of those services, information relating to individuals which appears in intelligence service archives shall not by itself constitute incriminating evidence, unless it is corroborated by several other reliable sources. PRINCIPLE 17. Specific Measures Related to the Restoration of or Transition to Democracy and/or Peace. (a) Measures shall be taken to place each archive centre under the responsibility of a specifically designated person. If that person was already in charge of the archive centre, he or she must be explicitly reappointed by special decision, subject to the modalities and guarantees provided in Principle 41. (b) Priority shall initially be given to inventorying stored archives and to ascertaining the reliability of existing inventories. Special attention shall be given to archives relating to places of detention, in particular when the existence of such places was not officially recognized. (c) The inventory shall be extended to relevant archives held by third countries, who shall be expected to cooperate with a view to communicating or restituting archives for the purpose of establishing the truth.

11 The Commission considered the report on 17 April 1998 (52nd meeting) and its resolution on impunity refers to it: C.H.R. res. 1998/53, ESCOR Supp. (No. 3) at 175, U.N. Doc. ECN.4/1998/53 (1998).

12 UN General Assembly, Resolution 61/177 adopted by the General Assembly: International Convention for the Protection of All Persons from Enforced Disappearance, 12 January 2007, A/RES/61/177.

13 Right to the Truth. Human Rights Resolution 2005/66, 20 April 2005.

14 Human Rights Council. Decision 2/105. Right to the Truth, 27 November 2006.

15 Commission on Human Rights. Study on the Right to the Truth, 8 February 2006. E/CN.4/2006/91.

16 Human Rights Council. Right to the Truth, 7 June 2007. A/HRC/5/.

17 Human Rights Council. Right to the Truth, para 4-31, 21 August 2009. A/ HRC/12/19.

18 Resolution adopted by the General Assembly on 18 December 2013. 68/165 Right to the Truth. A/RES/68/165.

19 Resolution adopted by the Human Rights Council, 13 October 2011. A/HRC/ RES/18/7.

20 ANNEX. "Set of general recommendations for truth commissions and archives". A: DE GREIFF, Pablo.- Report of the Special Rapporteur on the promotion of truth, justice, reparation and guarantees of non-recurrence. United Nations, 7 September 2015, A/HRC/30/42: Set of general recommendations for truth commissions and archives 
Introduction

1 Many post-authoritarian and post-conflict societies are faced with enormous challenges in the preservation and disposition of records containing information on gross human rights violations and serious violations of international humanitarian law. In many cases, secrecy, national security concerns, and poor archival practice stand in the way of guaranteeing the right to know the truth.

2 Archivists have, over time, developed sophisticated technical expertise and knowledge on all relevant issues regarding archives, including preservation, accessibility, and management. However, there is a striking gap between technical archival expertise and practice. Policies and practices that fall short of international standards risk the loss of records containing an important part of a society's heritage and hence hamper the possibility of accessing documentary evidence and support for efforts to achieve truth and justice.

3 Indeed, archives are relevant and can make significant contributions to each of the pillars of transitional justice, not merely truth and justice. At the same time, transitional justice measures can contribute to a country's archival system. Beyond the fact that transitional justice measures generate records themselves, truth commissions, trials, reparations programs and other transitional justice initiatives can contribute to improving archival practice both by the way they implement relevant standards with respect to their own documents, and because some of them, particularly truth commissions, are in a good position to make comments and recommendations about archival reform in general.

4 That potential, however, has not been consistently realized. Even truth commissions, both in post-authoritarian and post-conflict settings, manifest a significant gap between expertise and actual practice. There is little consistency in the disposition of truth commission archives, in the regimes that govern subsequent access to them, and in the recommendations that truth commissions make concerning archival systems.

5 In the conviction that these gaps need to be addressed, the Special Rapporteur on the promotion of truth, justice, reparation and guarantees of non-recurrence in his 2013 report to UN Human Rights Council on truth commissions (A/HRC/24/42) "calls for the development of international standards on archiving" for truth commissions. What follows is intended to contribute to the development of such standards. Part I contains recommendations for truth commissions pertaining to their own operations and the disposition of their archives, and Part II comprises recommendations that truth commissions can make regarding the establishment of national archival policies concerning records that contain information about gross human rights violations and serious violations of international humanitarian law.

a Both sets of recommendations build on well-established definitions on the "right to know" and on "archives" as stipulated in, among other places, the Updated Set of principles for the protection and promotion of human rights through action to combat impunity; see report of the independent expert Diane Orentlicher to update the Set of principles to combat impunity, E/CN.4/2005/102/Add.1, 8 February 2005.

$b$ For example, ISO 16363 defines a practice for assessing the trustworthiness of digital repositories.

6 As a general point, the Special Rapporteur would like to take the opportunity to reiterate the call on States to provide full support to truth-seeking mechanisms throughout their whole life-cycle, which includes access to records containing information on gross human rights violations and serious 
violations of international humanitarian law, in order for them to be able to effectively and independently implement their mandate.

\section{Recommendations for truth commissions}

In the context of their operations, truth commissions are encouraged to:

7 Build provisions for the eventual disposition of their records, guaranteeing both their safety and accessibility. This needs to be done in the early stages of planning their operations; a commission needs to decide who will be responsible for managing the records, where they will be stored in the short and long terms, and how access to them will be controlled.

8 Engage archival expertise in making and implementing those provisions during the life of the truth commission, and in this context take advantage of national (National Archives and Archival Associations) and international assistance and advice (e.g. International Council on Archives, Archivists without Borders);

9 Plan to deposit their archives in the country where the violations occurred and the commission operates, preferably in existing national archives, duly taking into account considerations of the security, integrity and accessibility of the archives. New and specialized archives may need to be created until such time as the national archives are able to adequately handle records of truth commissions. In the event of the possible loss, mutilation, poor preservation or destruction of the records in the country of origin, truth commissions should keep a complete, scanned and/or digitalized copy of the records in a secure facility outside the country or consider temporary preservation in a secure repository in a second jurisdiction or with an international institution;

10 Consider criteria having to do with preservation, accessibility, and trustworthiness of the host institution in deciding on the adequate repository.

11 Stipulate that the access policy of truth commission archives should maximize public accessibility, while respecting applicable privacy concerns, including in particular assurances of confidentiality provided to victims and other witnesses as a precondition of their testimony. Access to truth commission archives may not be denied on grounds of national security or other grounds unless the restriction is in full compliance with international human rights law;

12 Note that maximizing future accessibility has an impact on many operations of a commission throughout its lifetime, including, for example, on the process of taking statements and other contact with victims and witnesses who should be advised that their contributions to the commissions may be accessible in the future under specified conditions;

13 Establish guidelines for access to truth commission records, which shall take into account:

(a) General access rules, such as what was previously public should remain public; victims, families, investigative and prosecutorial authorities, as well as legal defence teams, should have unhindered access to information on their specific case; there should be a presumption of public access to all State information with only limited exceptions; a procedure to make effective the right of access should be established; whatever access rules are determined for various categories of potential users (for example, victims, legal representatives, journalists, academics, and members of the general public) should apply to all members of the given category without discrimination; 
(b) Categorization of records enabling familiar distinctions between types of documents (e.g. reports of own investigations, records of own meetings, victims' testimonies, documents obtained from other institutions, organizations, or private persons etc.) that will allow for a differentiated approach in facilitating access, in accordance with general access rules, to each type of document/collection;

(c) The need for effective mechanisms of reference services, as well as new technological advances in managing archives;

14 Develop, with the support of national and international expertise and assistance, provisions and measures to secure and preserve national archives, including by building effective and sustainable record management and archival systems, which includes, i.e., secure and adequate premises and clear appraisal policies;

15 Elaborate policies concerning relevant records and archives of non-State actors, including private businesses, so as to maximize effective management and access of these records by the truth commission.

II Possible recommendations by truth commissions

16 Regarding their recommendations on archives and the establishment of national archival policies that concern records containing information on gross human rights violations and serious violations of international humanitarian law, truth commissions are encouraged to:

17 Address the issue of reform of national archival legislation and institutions to encourage the establishment of modern, accessible, and reliable archives which are essential for the long-term preservation and use of records containing information on gross human rights violations and serious violations of international humanitarian law. Recommendations should include that reform efforts ought to be conducted with the participation of public institutions, civil society, and archival experts;

18 Make recommendations to preserve and actively use national archives, including archives of security services;

19 Call for independent oversight over the archives, including of archives of formerly repressive regimes;

20 Recommend the creation of archival laws, freedom of information legislation, data protection legislation and transparency requirements within other laws, which take into account the right to information, the right to know the truth, and the specificity of the records dealing with human rights violations and violations of international humanitarian law;

21 Recommend to the responsible authorities that they increase the capacity and where necessary the resources of State and local archival actors;

22 Recommend the provision by the State of information to the public on legal and practical requirements for access to archives;

23 Promote the establishment of comprehensive National Archival systems, including non-governmental records, especially those that are relevant to gross human rights violations and serious violations of international humanitarian law. Improvements in the regulation, disposition, protection and access to non-governmental archives (which does not involve the centralization of all records) will contribute to the establishment of such comprehensive systems, in accordance with international standards;

24 Recommend to the responsible authorities that they facilitate the work of civil society in the area of archives and ensure an enabling environment in this respect, in accordance with international standards; 
25 Reiterate that access to archives, containing records with information on gross human rights violations and serious violations of international humanitarian law, may not be denied to the public on grounds of national security unless the restriction is in full compliance with international human rights law.

21 Report of the Special Rapporteur on the promotion of truth, justice, reparation and guarantees of non-recurrence, para 80.12 October 2017. A/72/523.

22 Report of the Special Rapporteur on the promotion of truth, justice, reparation and guarantees of non-recurrence, para 49.25 July 2018. A/HRC/39/53.

23 "Rule-of-Law Tools for Post-Conflict States: Archives," United Nations High Commissioner for Human Rights series, 2015.

24 Decree 2726/83 of General Reynaldo Bignone. cf. Patricia Funes, Espionner, ficher, réprimer. La direction des services de renseignement de la police de la province de Buenos Aires et ses archives (Spy, record, punish. The Intelligence Services of the Police of the Province of Buenos Aires and their archives), La contemporaine, Matériaux pour l'histoire de notre temps 2006/1, no. 81, p. 105.

25 See the testimony of Red Brody (Human Rights Watch) in the film: Hissène Habré: La Traque d'un Dictateur (Canal+ France, 2009), And also in the Pierre Hazan's film: Chasseur de dictateurs. Article z, Arte, France, 2001.

26 The following institutions are part of the network:

1 Committee on Disclosure of Documents and Announcing Affiliation of Bulgarian Citizens to the State Security and the Intelligence Services of the Bulgarian National Army (Bulgaria).

2 Institute for the Study of Totalitarian Regimes and Security Services Archive (Czech Republic).

3 Federal Commissioner for the Records of the State Security Service of the former German Democratic Republic (Germany).

4 Historical Archive of the Hungarian State Security (Hungary).

5 Institute of National Remembrance Commission for the Prosecution of Crimes against the Polish Nation (Poland).

6 National Council for the Study of the Securitate Archives (Romania).

7 Nation's Memory Institute (Slovakia).

27 In Decree 5584 of 2005 , provision is made for the National Archives to collect the documents produced and received by the now defunct organizations that came under the authority of the Brazilian Intelligence Agency (Agência Brasileira de Inteligência): National Security Council (Conselho de Seguridade Nacional), General Investigations Commission (Comissão Geral de Investigações) and National Information Service (Serviço Nacional de Informações).

28 Kirsten Weld's essay Paper Cadavers (2014) is probably the best of its kind on the way these documents were recovered and used in Guatemala in the interests of human rights.

29 International Convention for the Protection of All Persons from Enforced Disappearances, Article 5: The widespread or systematic practice of enforced disappearance constitutes a crime against humanity as defined in applicable international law and shall attract the consequences provided for under such applicable international law.

30 Arns, P.E., dir. 1985, Um relato para a historia. Brasil: Nunca Mais. Sao Paulo: Arquidiocese de Sao Paulo, translated into English under the title, Torture in Brazil: A Shocking Report on the Pervasive Use of Torture by Brazilian Military Governments, 1964-1979. Austin: University of Texas Press, 1998. 
31 According to the online version of Encyclopaedia Britannica, the figure is "more than 35". Available at www.britannica.com/topic/truth-commission.

32 Law 21/2005 of 17 November on restitution to the Government of Catalonia (Generalitat de Catalunya) of documents seized during the Civil War kept at the General Archive of the Spanish Civil War (Archivo General de la Guerra Civil Española) and on creation of the Historical Memory Documentation Centre (Centro Documental de la Memoria Histórica).

33 In the original Spanish transcription, Barbie's alias was misspelled, the name under which he was known being Klaus Altmann Hansen and not Hausen.

34 Only in compensations to Holocaust survivors, Germany paid near 100 billion DM: "In September 1952 Adenauer reached agreement with Israeli Prime Minister Moshe Sharett to pay to Jewish survivors what would amount, through the years, to over DM100 billion" (Judt, 2005).

35 Principle 15. Housing, land and property records and documentation deserve a special mention:

15.1 States should establish or re-establish national multipurpose cadastral or other appropriate systems for the registration of housing, land and property rights as an integral component of any restitution Programme, respecting the rights of refugees and displaced persons when doing so.

15.2 States should ensure that any judicial, quasi-judicial, administrative or customary pronouncement regarding the rightful ownership of, or rights to, housing, land and/or property is accompanied by measures to ensure registration or demarcation of that housing, land and/or property as is necessary to ensure legal security of tenure. These determinations shall comply with international human rights, refugee and humanitarian law and related standards, including the right to be protected from discrimination.

15.3 States should ensure, where appropriate, that registration systems record and/or recognise the rights of possession of traditional and indigenous communities to collective lands.

15.4 States and other responsible authorities or institutions should ensure that existing registration systems are not destroyed in times of conflict or postconflict. Measures to prevent the destruction of housing, land and property records could include protection in situ or, if necessary, short-term removal to a safe location or custody. If removed, the records should be returned as soon as possible after the end of hostilities. States and other responsible authorities may also consider establishing procedures for copying records (including in digital format), transferring them securely and recognising the authenticity of said copies.

15.5 States and other responsible authorities or institutions should provide, at the request of a claimant or his or her proxy, copies of any documentary evidence in their possession required to make andlor support a restitution claim. Such documentary evidence should be provided free of charge, or for a minimal fee.

15.6 States and other responsible authorities or institutions conducting the registration of refugees or displaced persons should endeavour to collect information relevant to facilitating the restitution process, for example by including in the registration form questions regarding the location and status of the individual refugee's or displaced person's former home, land, property or place of habitual residence. Such information should be sought whenever information is gathered from refugees and displaced persons, including at the time of flight. 
15.7 States may, in situations of mass displacement where little documentary evidence exists as to ownership or rights of possession, adopt the conclusive presumption that persons fleeing their homes during a given period marked by violence or disaster have done so for reasons related to violence or disaster and are therefore entitled to housing, land and property restitution. In such cases, administrative and judicial authorities may independently establish the facts related to undocumented restitution claims. 15.8 States shall not recognise as valid any housing, land and/or property transaction, including any transfer that was made under duress, or which was otherwise coerced or forced, either directly or indirectly, or which was carried out contrary to international human rights standards.

36 The 187/1999 Lustration law would be declared unconstitutional by the Romanian Constitutional Court a few years later (Faraldo, 2018).

37 From 1954, CITRA organized gatherings in the interval between international Congresses for the Directors of National Archives and the presidents of national archival associations belonging to ICA. In 2013, it was replaced by a system of annual conferences open to all archiving professionals.

38 As a former Director of the National Commission on Computer Technology and Freedom (Commission nationale Informatique et Libertés - CNIL), Louis Joinet was no stranger to the world of archives.

39 Available at www.unesco.org/ulis/cgi-bin/ulis.pl?catno=140074\&set=005A58F0 8B_1_48\&gp=1\&mode=e\&lin=1\&ll=f.

40 Since 2009 , this newsletter has been produced by Trudy Huskamp Peterson, who chaired the group from 2009 to 2016.

41 Available at www.ica.org/en/hrwg-newsletters.

42 This practical guide consisting of 60 questions and compiled by Armelle Le Goff, in conjunction with the ICA's Section of International Organizations and prefaced by the UNESCO Director General, is intended for NGO managers and volunteers and its 30 odd pages offer basic advice on how to handle their records. It is available in eight languages on the ICA website. Available at www.ica.org/en/ records-ngos-memory-be-shared.

43 This is compliant with ICA standards (ISAD $(\mathrm{G})$, ISDF, ISDIAH, ISAAR (CPF) and designed specifically for the web. For further information, visit www.access tomemory.org/en/.

44 Available at www.arxivers.org/.

45 Available at http://archivesproject.swisspeace.ch/.

46 Available at http://archivesproject.swisspeace.ch/fileadmin/user_upload/archives project/Publications/DwP_Conceptual_Framework_October2012.pdf.

47 Basic Principles on the Role of Archivists and Records Managers in Support of Human Rights. Available at www.ica.org/sites/default/files/ICA\%20 HRWG\%20Basic\%20Principles_endorsed\%20by\%20PCOM_2016_Sept_ English.pdf.

48 Principle 15 of the Updated Set of Principles to Combat Impunity also states that "Access to archives should be facilitated, as necessary, for persons implicated who request such access for their defence."

49 Contribution of the UN system as a whole to the advancement of the business and human rights agenda and the dissemination and implementation of the Guiding Principles on Business and Human Rights. Report of the Secretary General, para 69 and 70.2, July 2012. A/HRC/21/21.

50 Internet Rights and Principles Coalition. The Charter of Human Rights and Principles for Internet. Internet Rights and Principles Dynamic Coalition (UN Internet Governance Forum), 2015. See also the resolution of the Council of Human Rights presented to the General Assembly of the United Nations: The promotion, 
protection and enjoyment of human rights on the Internet. United Nations document A/HRC/32/L.20, 2015.

51 The objective was to present the results of this survey at the 2nd Memory of the World (MoW) Global Policy Forum on Disaster Risk Reduction and Management for Sustainable Preservation of Documentary Heritage of UNESCO, which was scheduled to meet in Paris in October 2020 but was postponed until further notice due to the COVID-19 pandemic.

52 Available at www.ica.org/en/guiding-principles-for-safe-havens-for-archives-at-risk.

53 Designing the Archive. ICA Annual Conference Adelaide, South Australia, from 21 to 25 October 2019.

\section{Bibliography}

Alberch i Fugueras, Ramón. 2008, Archivos y derechos humanos. Gijón: Trea.

Arendt, Hannah. 1963, Eichmann in Jerusalem: A Report on the Banality of Evil. New York: Viking Press.

Banisar, David. 2006, Freedom of Information Around the World 2006: A Global Survey of Access to Government Information Laws. London: Privacy International.

Barahona, de Brito Alexandra, González, Enríquez Carmen, and Aguilar, Paloma, reds. 2001, The Politics of Memory: Transitional Justice in Democratizing Societies. Oxford: Oxford University Press.

Barrera, Giulia. 2011, "De cóndores y jueces: Reflexiones archivísticas sobre una investigación judicial,” Tabula, vol. 14.

Barrientos, Lizbeth, Bazaco, Blanca, González Quintana, Antonio, and Vega, Fernanda. 2018, "Los archivos en los Principios Ruggie y otros instrumentos internacionales contra las violaciones de derechos humanos en el mundo de los negocios," Informatio, vol. 23, no. 1, pp. 34-80.

Bassiouni, Cherif. 1999, Crimes Against Humanity in International Criminal Law. The Hague, Kluwer Law International.

— 2000, The Right to Restitution, Compensation and Rehabilitation for Victims of Gross Violations of Human Rights and Fundamental Freedoms. Final Report of the Special Rapporteur, Mr. Cherif Bassiouni, Submitted in Accordance with Commission Resolution 1999/33. Geneva: United Nations, Economic and Social Council, 18 January, E/CN.4/2000/62.

Baumgartner, Elizabeth, and Trudy, Peterson. 2017, Mapping Archives for Dealing with the Past Processes. Swisspeace. Available at http://archivesproject.swis speace.ch/resources/resource-collection/.

Bertrand, Jean-Wilfrid. 1988, "Les Archives nationales d'Haïti: près de deux siècles d'histoire, un nouveau depart," La Gazette des Archives, vol. 142-143, pp. 25-35.

Blazek, Peter. 2006, "Transitions to Democracy and the Lustration Screening Process," in: Transformation: The Czech Experience. Prague: People in Need with the Support of the Ministry of Foreign Affairs of the Czech Republic, pp. 173-180.

Borggräfe, Henning, Höschler, Christian, and Panek, Isabel. 2019, A Paper Monument: The History of the Arolsen Archive. Bad Arolsen: Arolsen Archives.

Brothman, Brien. 1993, "The Limits of Limits: Derridean Deconstruction and the Archival Institution," Archivaria, vol. 36, Autumn.

- 2001, "The Past That Archives Keep: Memory, History, and the Preservation of Archival Records," Archivaria, vol. 51. 
Cadelo, Valentina, and Peterson, Trudy H. 2018, "Principle 14: Measures for the Conservation of Archives"; "Principle 15: Measures for Facilitating Access to Archives"; "Principle 17: Specific Measures Relating to Archives Containing Names," in: Haldemann, Frank, and Unger, Thomas (eds.), The United Nations Principles to Combat Impunity: A Commentary. Oxford: Oxford University Press, pp. 163-180, 188-197.

Canavaggio, Perrine. 2014, Vers un droit d'accès à l'information publique: Les avancées récentes des normes et des pratiques. Paris: UNESCO.

Caso. 1998, El caso de España contra las dictaduras chilena y argentina: Los documentos del juez Garzón y la Audiencia Nacional. Barcelona: Planeta.

CIDH. 2015, Informe sobre la situación de los derechos humanos en la República Dominicana. Aprobado por la Comisión Interamericana de Derechos Humanos el 31 de diciembre de 2015. Comisión Interamericana de Derechos Humanos (CIDH). OEA/Ser.L/V/II. Doc.45/15. Available at http://www.oas.org/es/cidh/ informes/pdfs/republicadominicana-2015.pdf.

Cook, Terry. 1997, "What Is Past Is Prologue: A History of Archival Ideas Since 1898, and the Future Paradigm Shift," Archivaria, vol. 43, Spring.

Craig, Barbara L. 2002, "Selected Themes in the Literature on Memory and Their Pertinence to Archives," American Archivist, vol. 65.

Cruz, Luis M. 2010, "El derecho de reparación a las víctimas en el Derecho Internacional, Un estudio comparativo entre el Derecho Internacional de responsabilidad estatal y los Principios básicos de reparación de víctimas de derechos humanos," in: Revista de Derecho Político. $N^{\circ} 77$. Madrid: UNED, enero-abril.

Cunningham, Adrian. 2005, "Archival Institutions," in: Archives: Recordkeeping in Society. Cambridge: Chandos Publishing, pp. 21-50.

David, Roman. 2011, Lustration and Transitional Justice: Personnel Systems in the Czech Republic, Hungary, and Poland. Philadelphia: University of Pennsylvania Press, pp. 183, 209.

de Greiff, Pablo. 2013, Report of the Special Rapporteur on the Promotion of Truth, Justice, Reparation and Guarantees of Non-Recurrence. Pablo de Greiff: United Nations, 28 August, A/HRC/24/42.

- 2014, Report of the Special Rapporteur on the Promotion of Truth, Justice, Reparation and Guarantees of Non-Recurrence. Mission to Spain and Pablo de Greiff: United Nations, 22 July. A/HRC/27/56/Add.1.

- , 2015, Report of the Special Rapporteur on the Promotion of Truth, Justice, Reparation and Guarantees of Non-Recurrence. Pablo de Greiff, United Nations, 7 September, A/HRC/30/42.

- 2017, Report of the Special Rapporteur on the Promotion of Truth, Justice, Reparation and Guarantees of Non-Recurrence. Pablo de Greiff: United Nations, 12 October, A/72/523.

Doyle, Kate. 1999, "Death Squad Diary: Looking into the Secret Archives of Guatemala's Bureaucracy of Murder," Harper's Magazine, June.

Duchein, Michel. 1983, Obstacles to the Access, Use and Transfer of Information from Archives. RAMP Study, PGI-83/WS/20. Paris: UNESCO.

European. 2014, The "European Network of Official Authorities in Charge of the Secret Police Files" a Reader on the Legal Foundations, Structures and Activities. Berlin: BStU.

Faucheux, Michel. 2018, Olympe de Gouges. Paris: Gallimard. 
Foote, Kenneth E. 1990, "To Remember and Forget: Archives, Memory and Culture," The American Archivist, vol. 53.

González Quintana, Antonio. 1997, Archives of the Security Services of the Former Repressive Regime. Paris: UNESCO. Too in French in: Janus, 2. Paris: ICA, 1998.

— del pasado desde el comienzo de la transición," Hispania nova, Revista de Historia Contemporánea, vol. 7. Generaciones y memoria de la represión franquista: un balance de los movimientos por la memoria 2007.

_ 2009, Políticas archivísticas para la defensa de los derechos humanos. Paris: ICA.

— 2011, "Documentos sin fronteras para una justicia universal," Justicia, terrorismo y archivos. Tabula, $N^{\circ} 14$. Salamanca: ACAL.

- 2019a, "La experiencia del Archivo Histórico de la Policía Nacional de Guatemala (AHPN) como referente del uso de los archivos en defensa de los derechos humanos," Historia, trabajo y sociedad, vol. 10.

— 2019 b, "El Archivo Histórico de la Policía Nacional de Guatemala, en la encrucijada," Archivamos: Boletín ACAL, vol. 113, p. 28, Septiembre.

Harris, Verne. 1997, "Claiming Less, Delivering More: A Critique of Positivist Formulations of Archives in South Africa," Archivaria, vol. 44, Fall.

$\longrightarrow$, 2007, Archives and Justice. A South African Perspective. Chicago. Society of American Archivists.

Hayner, Priscilla B. 2001, Unspeakable Truths Transitional Justice and the Challenge of Truth Commissions. London: Routledge.

Heald, Carolyn. 1996, Is There Room for Archives in the Postmodern World? Available at https://www.jstor.org/stable/40293954.

Hobsbawm, Eric. 1995, The Age of Extremes: A History of the World, 1914-1991. London: Abacus.

Huntington, Samuel. 1993, The Third Wave: Democratization in the Late Twentieth Century. Norman: University of Oklahoma Press.

ICA. 2004, Proceedings of the XXXVIIth International Conference of the Round Table on Archives (CITRA). Cape Town, South Africa: ICA, 21-25 October; Comma 2004.

IGA. 2016, Records Management Code of Practice for Health and Social Care. London: Information Governance Alliance (IGA).

Joinet, Louis. 1997, Question of the Impunity of Perpetrators of Human Rights Violations (Civil and Political). Revised Final Report Prepared by Mr. Joinet Pursuant to Sub-Commission Decision 1996/119. United Nations, E/CN.4/ Sub.2/1997/20/Rev.1, 2 October. Available at http://www.derechos.org/nizkor/ impu/joinet 2. html.

— 2002, Lutter contre l'impunité: Dix questions pour comprendre et agir, dir. Louis Joinet. Paris: La Découverte.

Judt, Tony. 2005, Postwar: A History of Europe Since 1945. New York: Penguin Press.

Kaye, David. 2014, Archiving Justice: Conceptualizing the Archives of the United Nations International Criminal Tribunal for the Former Yugoslavia. Irvine: School of Law University of California, Legal Studies Research Paper Series No. 2014-34; Too in: Archival Science, vol. 14, pp. 3-4, October. 
Kecskeméti, Charles, and Székely, Iván. 2005, Access to Archives: A Handbook of Guidelines for Implementation of Recommendation R (2000) 13 on a European Policy on Access to Archives. Council of Europe. Available at https://book.coe. int/en/cultural-policies/3277-access-to-archives-a-handbook-of-guidelines-forimplementation-of-recommendation-no-r200013-on-a-european-policy-onaccess-to-archives.html.

Ketelaar, Eric. 1992, “Archives of the People, by the People, for the People," South African Archives Journal, vol. 34.

- 2002, "Tacit Narratives: The Meanings of Archives," Archival Science, vol. 1, no. 2, pp. 131-141.

Kitson, Simon. 2000, “Arresting Nazi Agents in Vichy France, 1940-1942,” In: Intelligence and National Security, p. 80, Spring.

Leitenberg, Milton. 2006, Deaths in Wars and Conflicts in the 20th Century. Ithaca: Cornell University Peace Studies Program.

Massaloux, Jean-Paul. 1989, La Régie de l'enregistrement et des domaines aux XVIIIe et XIXe siècles: Etude historique. Genève: Droz.

McNeil, Laurie. 2003, "Teaching an Old Genre New Tricks: The Diary on the Internet," Biography, vol. 26, pp. 24-47, Winter.

Mateva, Milena. 2006, Légitimité et Légalité. Considérations (sur la Loi et la Justice) à l'image de deux grands procès politiques [Procès Barbie - Procès Honecker]. Thèse présentée à la Faculté des sciences économiques et sociales de l'Université de Neuchâtel.

Millar, Laura. 2006, "Touchstones: Considering the Relationship Between Memory and Archives," Archivaria: The Journal of The Association of Canadian Archivists/Production, vol. 61, pp. 105-126, Spring, University of Toronto Press.

Noiriel, Gérard. 1993, "L'identification des citoyens. Naissance de l'état civil républicain,” Genèses, vol. 13, pp. 3-2.

Ollé Sesé, Manuel. 2009, “The Advance of Universal Justice,” FIDH, Spain Universal Jurisdiction, 27 May. Available at https:/www.fidh.org/en/region/europe-centralasia/spain/The-advance-of-universal-justice.

Olson, Laura. 2002, "Mechanisms Complementing Prosecution," IRRC, vol. 84, no. 845 , March.

Orentlicher, Diane. 2005, Promotion and Protection of Human Rights. Report of the Independent Expert to Update the Set of Principles to Combat Impunity, Diane Orentlicher, UN Doc. E/CN.4/2005/102, 18 February and Updated Set of Principles for the Protection and Promotion of Human Rights Through Action to Combat Impunity, UN Doc, 8 February. E/CN.4/2005/102/Add.1. Available at https://ap.ohchr.org/documents/alldocs.aspx?doc_id=10800.

Pérotin-Dumon, Anne. 2007, "Les archives de la défense des droits humains en Amérique latine: Chili, Argentine, Pérou," La Gazette des archives, vol. 206, pp. 45-94.

Peterson, Trudy H. 2005, Final Acts: A Guide to Preserving Records of Truth Commissions, Baltimore, MD: Johns Hopkins University Press.

- 2006, Temporary Courts, Permanent Records: Special Report. Washington, DC: United States Institute of Peace.

. 2011, "El valor probatorio del documento de archivo en los procesos judiciales," Tabula, vol. 14, Salamanca.

- 2014, The Probative Value of Archival Documents. Bern: Swisspeace. 
2018a, "Proof," Informatio, Revista del Instituto de Información y Comunicación, vol. 23, no. 1. Archivos y Derechos Humanos, Montevideo.

- 2018b, The Universal Declaration of Human Rights: An Archival Commentary. Paris: International Council on Archives - Human Rights Working Group.

Pinheiro, Sergio. 2005, Economic, Social and Cultural Rights: Housing and Property Restitution in the Context of the Return of Refugees and Internally Displaced Persons Final Report of the Special Rapporteur, Paulo Sérgio Pinheiro Principles on Housing and Property Restitution for Refugees and Displaced Persons. Geneva: United Nations, Economic and Social Council. E/CN.4/ Sub.2/2005/17.

Primera, Mayte. 2013, Medio millón de apátridas por una sentencia del Supremo dominicano; Los dominicanos hijos de haitianos, en el limbo entre dos sentencias: La sentencia que niega la nacionalidad a los descendientes de 'sin papeles' obvia un fallo de 2005 de la Corte Interamericana. Madrid: El País, 20, 22 de octubre de.

Ridener, John. 2009, From Polders to Postmodernism: A Concise History of Archival Theory. Sacramento: Litwin Books.

Rodríguez, Jorge. 2017, Derecho a la verdad y derecho internacional en relación con graves violaciones de los derechos humanos Madrid: Fundación Instituto Berg, año.

Ruggie, John. 2011, Guiding Principles on Business and Human Rights: Implementing the United Nations "Protect, Respect and Remedy" Framework. Geneva: United Nations, A/HRC/17/31, 21 March.

Salinas, Alejandro. 2005, Basic Principles and Guidelines on the Right to a Remedy and Reparation for Victims of Gross Violations of International Human Rights Law and Serious Violations of International Humanitarian Law Human Rights Resolution 2005/35. Geneva: Office of the High Commissioner for Human Rights.

Salvioli, Fabián. 2018, Report of the Special Rapporteur on the Promotion of Truth, Justice, Reparation and Guarantees of Non-Recurrence. Geneva: United Nations, 25 July, A/HRC/39/53.

- 2020, Memorialization Processes in the Context of Serious Violations of Human Rights and International Humanitarian Law: The Fifth Pillar of Transitional Justice. Report of the Special Rapporteur on the Promotion of Truth, Justice, Reparation and Guarantees of Non-recurrence. United Nations, A/ HRC/45/45, 9 July.

Sanford, George. 2005, Katyn and the Soviet Massacre of 1940: Truth, Justice and Memory. London and New York: Routledge.

Schiller-Dickhut, Reiner, and Rosenthal, Bert. 2014, 'European Network of Official Authorities in Charge of the Secret Police Files': A Reader on the Legal Foundations, Structures and Activities. Berlin: BstU.

Schrimm, Kurt, and Riedel, Joachim. 2008, "50 Jahre Zentrale Stelle in Ludwigsburg: Ein Erfahrungsbericht über die letzten zweieinhalb Jahrzehnte $=50$ Years Central Office in Ludwigsburg: An Empirical Account of the Last Two-and-a-Half Decades," Vierteljahrshefte für Zeitgeschichte, vol. 56, no. 4.

Schwartz, Herman. 1995, "Lustration in Eastern Europe," in: Transitional Justice: How Emerging Democracies Reckon with Former Regimes, vol. 1. Washington, DC: United States Institute of Peace Press. 
Schwartz, Joan M., and Cook, Terry. 2002, “Archives, Records, and Power: The Making of Modern Memory," Archival Science, vol. 2, pp. 1-19.

Svärz, Proscovia. 2009, "Archiving Challenges in Africa: The Case of PostConflict Liberia," IASA Journal: International Association of Sound and Audiovisual Archives, vol. 32.

Trial. 1947, Trial of the Major War Criminals Before the International Military Tribunal: Nuremberg, 14 November 1945.1 October 1946; Documents and Other Material Evidences (vols. XXV ....). Nuremberg. Available at https://www. loc.gov/rr/frd/Military_Law/pdf/NT_Vol-I.pdf.

Turrión, María José. 2013, "Políticas públicas de reparación en España: La ley 52/2007 sobre memoria histórica en relación a la identificación y localización de las víctimas desaparecidas durante la Guerra Civil y la dictadura," Alcores: revista de historia contemporánea, vol. 15, pp. 207-226.

UN-HCHR. 2006, Rule-of-Law Tools for Post-Conflict States: Prosecution Initiatives. HR/PUB/06/04. Geneva: United Nations High Commissioner for Human Rights.

. 2015, Rule-of-Law Tools for Post-Conflict States: Archives. HR/PUB/06/04. Geneva: United Nations High Commissioner for Human Rights.

United Nations, General Assembly. 2006, Basic Principles and Guidelines on the Right to a Remedy and Reparation for Victims of Gross Violations of International Human Rights Law and Serious Violations of International Humanitarian Law: Resolution Adopted by the General Assembly on 16 December 2005, 21 March. A /RES/60/147. Geneva: United Nations.

United Nations, Security Council. 2004, The Rule of Law and Transitional Justice in Conflict and Post-Conflict Societies. Report of the Secretary-General, 23 August. S/2004/616.

Van Boven, Theo. 1993, United Nations Commission on Human Rights: Study Concerning the Right to Restitution, Compensation and Rehabilitation for Victims of Gross Violations of Human Rights and Fundamental Freedoms: Final Report. Theo van Boven, Special Rapporteur, UN Doc. E/CN.4/Sub.2/1993, 8 July. Geneva: United Nations.

Waldman, Gilda. 2006, "La cultura de la memoria: problemas y reflexiones," Política y cultura, vol. 26, Otoño.

Weld, Kirsten. 2014, Paper Cadavers: The Archives of Dictatorship in Guatemala. Durham, NC: Duke University Press. 